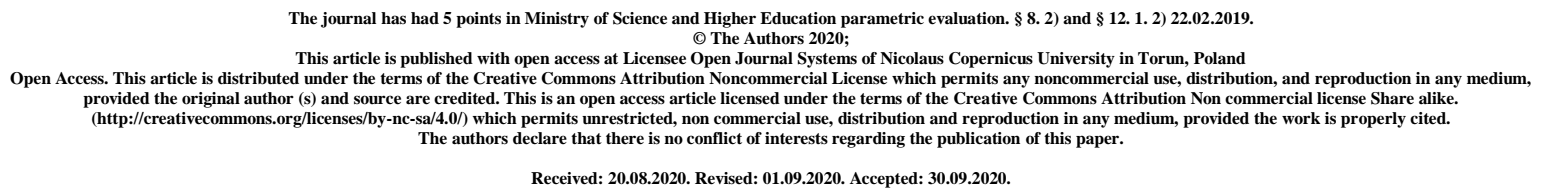

UDK 616.71-053.2-06:616-056.25]-07

\title{
DIAGNOSTIC POSSIBILITIES OF DETERMINATION OF OSTEOGENESIS DISORDERS IN CHILDREN BORN WITH LOW BODY WEIGHT
}

\author{
T. Ye. Shumna, T. O. Levchuk-Vorontsova
}

\section{Zaporizhzhia State Medical University, Zaporizhzhia, Ukraine}

Shumna T. Ye., MD, PhD, DSc, Professor of the Department of Faculty Pediatry, Zaporizhzhia State Medical University, Ukraine; 28A, Novgorodskaia street, Zaporizhzhia, 69076; Tel .:+380978541809, e-mail: tshumnaya72@gmail.com

ID orcid 0000-0003-4926-1271

Levchuk-Vorontsova T.O., MD, Assistant of the Department of Children Diseases, Zaporizhzhia State Medical University, Ukraine; 28A, Novgorodskaia street, Zaporizhzhia, 69076; Tel .: +380674352467, e-mail: tatyana0702@gmail.com

ID orcid 0000-0003-0557-6714

\section{Abstract}

The work aims at studying the bone tissue mineral density in children born with low body weight, taking into account the dependence on the nature of feeding and polymorphism of the C/A gene polymorphism of COL1A1_1 collagen gene (rs1107946).

Materials and methods. The study involved 74 children. Of these, 29 children born with the body weight of 1500-1999 g were in the observation group I; 25 children weighing 2000-2499 g - group II; 20 children with the body weight at birth of $2500 \mathrm{~g}$ - group III (control group). All children were under inpatient treatment at the Municipal Non-Profit Enterprise "City Children Hospital no. 5" of Zaporizhia City Council. Data on the type of breastfeeding of a child aged under 1 year were analyzed for all children. The study of bone 
tissue mineral density was performed at the age of 12-15 months using an ultrasonic bone sonometer (densitometer) Sunlight MINIOMNI) BeamMed Ltd., Israel. The examination was conducted at the Department of Faculty Pediatrics of the Zaporizhia State Medical University. Analysis of the results was performed by non-parametric statistics methods using the Statistica 13 software package. Ordinal descriptive statistics was used to calculate the average Z-score indicators. The non-parametric statistical method " $2 \times 2$ Table", the Chi-square ( $\mathrm{df}=$ 1) was used to compare the frequencies of desitometry indicators in different groups.

Results. In general, among the examined children according to densitometry data, there were no changes in the skeletal system (Z-score $0.48 \pm 1.20)$ in $64.86 \%$ of cases, but there were osteopenia (Z-score $-1.8 \pm 0,53$ ) in $27.03 \%$ and osteoporosis (Z-score $-3.5 \pm 0.96$ ) in $8.11 \%$. But in the further analysis by groups, the average Z-score indicator in children of the group I was $0.37 \pm 2.06$, in children of the group II $--0.08 \pm 1.59$ and in children of the group III $-0.47 \pm 1,69$. But in children of the group I with body weight at birth $1500-1999 \mathrm{~g}$, osteopenia was registered in $34.48 \%$ of cases; the group II (2000-24999 g) - in $28.00 \%$ of cases; the group III (2500 g and more) - in $15.00 \%$ of cases. Osteoporosis was found only among children of the groups I and II. Children of the group I mainly received artificial and mixed feeding. Children of the group II received approximately the same amount of natural and artificial feeding, much less often mixed one, and $50 \%$ of children of the group III were on natural feeding. The Z-score indicators less than -1SD were found in children with AA and CA genotypes. Osteopenia was significantly less common in children with the AA genotype of the C/A gene polymorphism of COL1A1_1 collagen gene (rs1107946), who received natural or mixed feeding than in children who were exclusively on artificial feeding $(\mathrm{p}<0.05)$. Among children with the AA genotype who were breastfed, there were changes in bone tissue (63.64\% of children had osteopenia and $22.73 \%$ had osteoporosis). Among heterozygotes who were on artificial feeding, osteoporosis was found in $12.5 \%$. Children with the CA genotype on mixed feeding had a decrease in bone tissue density (osteopenia) in $33.33 \%$ of cases. Children with AA genotype who were breastfed and had osteopenia, these were children weighing up to $2500 \mathrm{~g}$ (groups I and II). Children with osteopenia on mixed breastfeeding weighed at birth up to $2000 \mathrm{~g}$. Osteopenia in children receiving artificial feeding was found in children of all 3 groups: 50.00\% - group I, 28.57\% - group II and 21, $43 \%$ - group III. Osteoporosis in breastfed children was found only among children of the groups I and II.

Conclusions. According to densitometry data, among all examined children, there were no changes in the skeletal system (Z-score $0.48 \pm 1.20$ ) in $64.86 \%$, osteopenia was 
registered (Z-score - $1.8 \pm 0.53$ ) in $27.03 \%$ and osteoporosis (Z-score $-3.5 \pm 0.96$ ) was registered in $8.11 \%$. But in children of the group I with body weight at birth of $1500-1999 \mathrm{~g}$, osteopenia was registered in $34.48 \%$ of cases; in the group II (2000-24999) in $28.00 \%$ of cases; in the group III (2500 g and more) in $15.00 \%$ of cases. Osteoporosis was found only among children born weighing up to $2500 \mathrm{~g}$. Children of the group I mainly received artificial $(62.07 \%)$ and mixed (34.48\%) feeding. Children of the group II received approximately the same amount of natural (40.00\%) and artificial (44.00\%) feeding, much less often mixed one. In the control group III, $50 \%$ of children were breastfed. Regardless of the type of feeding, no changes in bone tissue were detected in children with the $\mathrm{CC}$ genotype of the C/A gene polymorphism of COL1A1_1 collagen gene (rs1107946). The Z-scores indicators less than -1 SD were found in children with the AA and CA genotypes, and only among children with the AA genotype of polymorphism, who received natural or mixed feeding, osteopenia occurred significantly less frequently $(30.00 \%)$ than among children who had exclusively artificial feeding (63.64\%). Osteoporosis was detected only in children with the AA genotype (12.5\%) who were on artificial feeding.

Key words: children born with low body weight; premature babies; densitometry; osteoporosis; osteopenia; breastfeeding; artificial feeding; mixed feeding; C/A gene polymorphism of COL1A1_1 collagen gene (rs1107946).

\title{
ДІАГНОСТИЧНІ МОЖЛИВОСТІ ВИЗНАЧЕННЯ ПОРУШЕНЬ ОСТЕОГЕНЕЗУ У ДІТЕЙ, НАРОДЖЕНИХ 3 МАЛОЮ МАСОЮ ТІЛА
}

\author{
Т. Є. Шумна, Т. О. Левчук-Воронцова
}

Запорізький державний медичний університет, Запоріжжя, Україна

Мета роботи. Вивчення мінеральної щільності кісткової тканини у дітей, що були народжені 3 малою масою тіла 3 урахуванням в залежності від характеру вигодовування та поліморфізму гену C / А гена колагену COL1A1_1 (rs1107946).

Матеріали та методи. У дослідженні взяли участь 74 дитини. 3 них 29 дітей, що були народжені за масою тіла 1500-1999г склалось I групу спостереження; 25 дитини 3 масою тіла 2000-2499 - II групу; 20 дитини з масою тіла 2500г - склалось III групу, або групу контролю. Всі діти знаходились на стаціонарному лікуванні в Комунальному неприбуткових підприємстві «Міська дитяча лікарня № 5» Запорізької міської ради. У 
всіх дітей були проаналізовані дані стосовно виду вигодовування дитини до 1 року. Вивчення мінеральної щільності кісткової тканини проводилося у віці 12-15 місяців 3 використанням ультразвукового кісткового сонометра (денситометра) «Sunlight MINIOMNI») BeamMed Ltd., Ізраїль. Обстеження проводилося на кафедрі факультетської педіатрії ЗДМУ. Аналіз результатів був виконаний з використанням методів непараметричної статистики 3 допомогою пакету програм Statistica 13. Для обчислення середніх показників Z-score була використана ordinal descriptive statistics. Для порівняння частот показників денситометрії в різних групах використовували непараметричний статистичний метод «2 $\times 2$ Table », the Chi-square $(\mathrm{df}=1)$.

Результати. Взагалі, серед обстежених дітей за даними денситометрії у 64,86\% не було виявлено змін з боку кісткової системи (Z-score 0,48 $\pm 1,20$ ), у 27,03\% остеопенія (Z-score) $-1,8 \pm 0,53$ ) та у $8,11 \%$ - остеопороз (Z-score $-3,5 \pm 0,96)$. Але при подалі аналізі по групам середній показник Z-score у дітей I групи склав $-0,37 \pm 2,06$, y дітей II групи - - 0,08 \pm 1,59, у дітей III групи - 0,47 $\pm 1,69$. Так, у дітей I групи з масою тіла при народжені 1500-1999 г, остеопенія реєструвалась у 34,48\% обстежених; II групи (2000-24999 г) - в 28,00\% випадків; III групи (2500г та більше) - у 15,00\% дітей. Остеопороз був виявлений лише серед дітей I та II груп. Діти I групи в цілому отримували штучне та змішане вигодування. Діти II групи приблизно однаково отримувалася природньо та штучне вигодовування, значний рідше змішане, та 50\% дітей III групи знаходились на природному відгодовувані. Показники Z-score менше 1SD були виявлені у дітей з генотипом AA та CA. Серед дітей з генотипом АA поліморфізму гену C / А гена колагену COL1A1_1 (Rs1107946), що отримувалася природне або змішане вигодовування достовірно рідше зустрічалась остеопенія, порівняно з дітьми, що були виключно на штучному вигодовуванні $(<0,05)$. Серед дітей 3 генотипом АА, що були на штучному вигодовуванні, мали зміни 3 боку кісткової тканини (63,64\% дітей мали остеопенію та 22,73\% мали остеопороз). Серед гетерозигот, що були на штучному вигодовуванні, у 12,5\% виявило остеопороз. Діти 3 генотипом СА на змішаному вигодовуванні мали зниження щільності кісткової тканини (остеопенію) у 33,33\%. Діти з генотипом АА, що були на грудному вигодовуванні та мали остеопенію, це були діти з вагою при Народжені до 2500г (I та II групи). Діти з остеопенією на змішаному вигодовуванні мали вагу при народжені до 2000 г остеопенія у дітей, що отримувалася штучне вигодовування, була виявлено у дітей трьох груп: 50,00\% -I група, 28,57\% - II група та 21,43\% - III група. Остеопороз у дітей на штучному вигодовуванні був виявлений лише серед дітей I та II групи. 
Висновки. Серед всіх обстеження дітей, за даними денситометрії, у 64,86\% не було виявлено змін з боку кісткової системи (Z-score 0,48 $\pm 1,20$ ), у 27,03\% реєструвалась остеопенія (Z-score $-1,8 \pm 0,53$ ) та у 8,11\% - остеопороз (Z-score $-3,5 \pm$ 0,96). Але у дітей I групи $з$ масою тіла при народжені 1500-1999 г, остеопенія реєструвалась у 34,48\% обстеження; II групи (2000-24999 г) - в 28,00\% випадка; III групи (2500г та більше) - у 15,00\% дітей. Остеопороз був виявлений лише серед дітей, що були народжені з масою тіла до 2500г. Діти I групи переважно отримували штучне та змішане вигодування. Діти II групи приблизно однаково отримувалася природньо та штучне вигодовування. Серед дітей групи контролю 50\% дітей були на природному відгодовувані. У дітей з генотипом СС поліморфізму гену С / А гена колагену COL1A1_1 (rs1107946), незалежно від виду вигодовування, не було виявлено змін 3 боку кісткової тканини. Показники Z-score менше -1 SD були виявлені у дітей $з$ генотипом АА та СА, тільки серед дітей з генотипом АА, що отримували природне або змішане вигодовування, достовірно рідше зустрічалась остеопенія порівняно 3 дітьми, що були виключно на штучному вигодовуванні $(63,64 \%)$. Остеопороз був виявлений тільки у дітей з генотипом АА (12,5\%), що отримували штучне вигодовування.

Ключові слова: діти, що народжені 3 малою масою тіла; передчасно народжені діти; денситометрія; остеопороз; остеопенія; грудне вигодовування; штучне вигодовування; змішане вигодовування; поліморфізм гену С / А гена колагену COL1A1_1 (rs1107946).

\section{ДИАГНОСТИЧЕСКИЕ ВОЗМОЖНОСТИ ОПРЕДЕЛЕНИЯ НАРУШЕНИЙ ОСТЕОГЕНЕЗА У ДЕТЕЙ, РОЖДЕННЫХ С НИЗКОЙ МАССОЙ ТЕЛА}

\section{Т. Е. Шумная, Т. О. Левчук-Воронцова}

\section{Запорожский государственный медицинский университет, Запорожье, Украина}

Целью работы является изучение минеральной плотности костной ткани у детей, рожденных с низкой массой тела с учетом характера вскармливания и полиморфизма гена C / А гена коллагена COL1A1_1 (rs1107946).

Материалы и методы. В исследовании приняли участие 74 ребенка. Из них 29 детей, которые были рождены за массой тела 1500-1999г составили I группу наблюдения; 25 ребенка с массой тела 2000-2499 - II группу; 20 ребенка с массой тела 
2500г - вошли в III группу, или группу контроля. Все дети находились на стационарном лечении в коммунальном неприбыльном предприятии «Городская детская больница № 5» Запорожского городского совета. У всех детей были проанализированы данные о виде вскармливания до 1 года. Изучение минеральной плотности костной ткани проводилось в возрасте 12-15 месяцев с использованием ультразвукового костного сонометра (денситометра) «Sunlight MINIOMNI») BeamMed Ltd., Израиль. Обследование проводилось на кафедре факультетской педиатрии ЗГМУ. Анализ результатов был выполнен с использованием методов непараметрической статистики с помощью пакета программ Statistica 13. Для вычисления средних показателей Z-score была использована ordinal descriptive statistics. Для сравнения частот показателей денситометрии в разных группах использовали непараметрический статистический метод «2 $\times 2$ Table», the Chi-square $(\mathrm{df}=1)$.

Результаты. В целом, среди обследованных детей по данным денситометрии в 64,86\% не было выявлено изменений со стороны костной системы (Z-score 0,48 $\pm 1,20$ ), в $27,03 \%$ - остеопения (Z-score) $-1,8 \pm 0,53$ ) и в $8,11 \%$ - остеопороз (Z-score $-3,5 \pm 0,96$ ). Но при подальше анализе по группам средний показатель Z-score у детей I группы составил -0,37 $\pm 2,06$, у детей II группы - - 0,08 \pm 1,59, у детей III группы - 0,47 $\pm 1,69$. Так, у детей I группы с массой тела при рождении 1500-1999 г, остеопения регистрировалась в 34,48\% обследованных; II группы (2000-24999 г) - в 28,00\% случаев; III группы (2500г и более) - в 15,00\% детей. Остеопороз был обнаружен только среди детей I и II групп. Дети I группы в целом получали искусственное и смешанное вскармливание. Дети II группы примерно одинаково получалась естественно и искусственное вскармливание, значительный реже смешанное, и 50\% детей III группы находились на естественном откармливаемых. Показатели Z-score меньше -1SD были обнаружены у детей с генотипом АА и СА. Среди детей с генотипом АА полиморфизма гена C / А гена коллагена COL1A1_1 (Rs1107946), что приобреталась естественное или смешанное вскармливание достоверно реже встречалась остеопения, по сравнению с детьми, которые были исключительно на искусственном вскармливании $(<0,05)$. Среди детей с генотипом AА, которые были на искусственном вскармливании, имели изменения со стороны костной ткани $(63,64 \%$ детей имели остеопения и 22,73\% имели остеопороз). Среди гетерозигот, которые были на искусственном вскармливании, в 12,5\% выявило остеопороз. Среди детей с генотипом CA на смешанном вскармливании было виявлено снижение плотности костной ткани (остеопения) в 33,33\%. Дети с генотипом АА, которые были на грудном вскармливании 
с остеопенией, имели вес при рождении в 2500г (I и II группы). Дети с остеопенией на смешанном вскармливании имели вес при рождении до 2000 г. Остеопения у детей, которые получали искусственное вскармливание, была выявлена во всех группах: $50,00 \%$-I группа, 28,57\% - II группа и 21,43\% - III группа. Остеопороз у детей на искусственном вскармливании был обнаружен только среди детей I и II группы с генотипом АА и СА.

Выводы. Среди всех обследование детей, по данным денситометрии, в 64,86\% не было выявлено изменений со стороны костной системы (Z-score 0,48 $\pm 1,20)$, в $27,03 \%$ - регистрировалась остеопения (Z-score $1,8 \pm 0,53)$ и в $8,11 \%$ - остеопороз (Zscore $-3,5 \pm 0,96)$. Но у детей I группы с массой тела при рождении 1500-1999 г, остеопения регистрировалась в 34,48\% обследования; II группы (2000-24999 г) - в $28,00 \%$ случаях; III группы (2500г и более) - в 15,00\% детей. Остеопороз был обнаружен только среди детей, которые были рождены с массой тела до 2500г. Дети I группы преимущественно получали искусственное и смешанное вскармливание. Дети II группы примерно одинаково получалась естественно и искусственное вскармливание. Среди детей группы контроля 50\% детей были на естественном вскармливаемых. У детей с генотипом СС полиморфизма гена С / А гена коллагена COL1A1_1 (rs1107946), независимо от вида вскармливания, не было выявлено изменений со стороны костной ткани. Показатели Z-score меньше -1 SD были обнаружены у детей с генотипом АА и СА, только среди детей с генотипом АA, получавших естественное или смешанное вскармливание, достоверно реже встречалась остеопения сравнению с детьми, которые были исключительно на искусственном вскармливании (63,64 \%). Остеопороз был обнаружен только у детей с генотипом АА (12,5\%), получавших искусственное вскармливание.

Ключевые слова: дети, рожденные с низкой массой тела преждевременно рожденные дети; денситометрия; остеопороз остеопения; грудное вскармливание; искусственное вскармливание; смешанное вскармливание; полиморфизм гену С / А гена коллагена COL1A1_1 (rs1107946).

Introduction. Preservation of the children's health is a pressing issue today. At present, scientists and practitioners are actively engaged in study of the problem of osteogenesis disorders.

It is known that metabolic bone diseases (MBD) in newborns, osteopenia, neonatal rickets or rickets of premature babies are terms used to describe the decrease in mineral 
content in bones in premature infants. Babies born prematurely are usually "deprived" of the period of intrauterine life, which provides the supply of minerals to create optimal bone mineralization at birth. It is known that the frequency of occurrence of MBD is inversely related to birth weight and gestational age. Other factors that interfere with normal bone mineralization include artificial feeding, low intake of vitamin D, calcium (Ca) and phosphorus (P) at an early age, long periods of parenteral nutrition and side effects of diuretics and corticosteroids prescribed to these children [1 - 4].

At the same time, as of today, there are no specific methods for diagnosing metabolic diseases in premature babies [2]. And a direct study of $\mathrm{Ca} 2+$ cannot be a screening test, since newborns can maintain a normal level of $\mathrm{Ca} 2+$ for a long time due to its mobilization from the bones [5,6]. And determination of other markers of osteopenia, such as the level of osteocalcin and $1,25 \mathrm{OH}$-vitamin $\mathrm{D}$, is not always possible; in addition, it is financially expensive and therefore not available to everyone. Although the increased alkaline phosphatase level is a reliable indicator of bone demineralization in premature babies, the normal levels also do not guarantee normal bone condition [7].

In adult practice, various densitometry methods are used to quantitatively diagnostics of bone density. The standard of densitometry in adult practice is the Dual Energy X-ray Absorptiometry (DXA). In pediatrics, this method is used only for scientific researches, since the radiation load, the need to transport the child, the lack of programs and standards for examining newborns and children aged 1 year limit its use in clinical practice. For the same reasons, quantitative computed tomography is not used in practice. The X-ray signs of osteopenia appear when mineralization is already reduced by $20-40 \%$ and is characterized by bone thinning, thickening of the diaphyses, subperiosteal growths and fractures. But instrumental diagnostics of the bone disorders in premature infants remains a great challenge.

Today, the method of quantitative ultrasound densitometry is being introduced into the practical health care of Ukraine and other countries of the world, in particular for cases of premature babies and in children aged 1 year in general [8].

In this case, the Z-score is used in children. The Z-score is considered as the value of the standard deviation of the actual bone density relative to the corresponding average age indicator. Z-scores of up to -1SD are considered normal, from -1SD to -2.5 SD as osteopenia and more than -2.5 SD as osteoporosis. At the same time, a decrease in bone mineral density is also clinically identified as osteopenia or osteoporosis, which, according to the World Health Organization, today ranks fourth among non-infectious diseases in the world [9]. 
The work aims at study the bone tissue mineral density in children born with low body weight, taking into account the dependence on the nature of feeding and polymorphism of the C/A gene polymorphism of COL1A1_1 collagen gene (rs1107946).

Materials and methods. The study involved 74 children. Of these, 29 children born with the body weight of 1500-1999 g were in the observation group I; 25 children weighing 2000-2499 g - group II; 20 children with the body weight at birth of $2500 \mathrm{~g}$ - group III (control group). All children were under inpatient treatment at the Municipal Non-Profit Enterprise "City Children Hospital no. 5" of Zaporizhia City Council. Data on the type of breastfeeding of a child aged under 1 year were analyzed for all children. The study of bone tissue mineral density was performed at the age of 12-15 months using an ultrasonic bone sonometer (densitometer) Sunlight MINIOMNI) BeamMed Ltd., Israel. The examination was conducted at the Department of Faculty Pediatrics of the Zaporizhia State Medical University.

Analysis of the results was performed by non-parametric statistics methods using the Statistica 13 software package. Ordinal descriptive statistics was used to calculate the average Z-score indicators. The non-parametric statistical method " $2 \times 2$ Table", the Chi-square $(\mathrm{df}=$ 1) was used to compare the frequencies of desitometry indicators in different groups.

Results. In general, among the examined children according to densitometry data, there were no changes in the skeletal system (Z-score $0.48 \pm 1.20$ ) in $64.86 \%$ of cases, but there were osteopenia (Z-score $-1.8 \pm 0,53$ ) in $27.03 \%$ and osteoporosis (Z-score $-3.5 \pm 0.96$ ) in $8.11 \%$. But in the further analysis by groups, the average Z-score indicator in children of the group I was $0.37 \pm 2.06$, in children of the group II $--0.08 \pm 1.59$ and in children of the group III $-0.47 \pm 1,69$. But in children of the group I with body weight at birth $1500-1999 \mathrm{~g}$, osteopenia was registered in $34.48 \%$ of cases; the group II (2000-24999 g) - in $28.00 \%$ of cases; the group III (2500 g and more) - in $15.00 \%$ of cases. Osteoporosis was found only among children born weighing up to $2500 \mathrm{~g}$. These data are shown in the Table 1.

Table 1. Desitometry indicators depending on the weight at birth

\begin{tabular}{|l|l|l|l|l|l|l|}
\hline \multicolumn{1}{|c|}{ Groups } & $\begin{array}{c}\text { Normal } \\
\text { value }\end{array}$ & \multicolumn{1}{|c|}{ Z-score } & Osteopenia & Z-score & Osteoporosis & Z-score \\
\hline Group I & $51,72 \%$ & $0,78 \pm 1,0$ & $34,48 \%^{*}$ & $-1,98 \pm 0,56$ & $13,79 \%$ & $-3,9 \pm 0,96$ \\
\hline Group II & $64,00 \%$ & $0,88 \pm 1,01$ & $28,00 \%$ & $-1,53 \pm 0,51$ & $8,00 \%$ & $-2,74 \pm 0,21$ \\
\hline Group III & $85,00 \%$ & $0,88 \pm 1,47$ & $15 \% *$ & $-1,87 \pm 0,29$ & - & - \\
\hline
\end{tabular}

Further analysis by groups of densitometry results taking into account the type of feeding showed that children weighing up to $2000 \mathrm{~g}$ mainly received artificial and mixed 
feeding. Children of the group II received approximately the same amount of natural and artificial feeding, much less often mixed one, and 50\% of children of the group III were on natural feeding.

Table 2. Distribution of the type of feeding depending on the weight at birth

\begin{tabular}{|l|l|l|l|}
\hline \multicolumn{1}{|c|}{ Groups } & \multicolumn{1}{c|}{ Natural feeding } & \multicolumn{1}{c|}{ Artificial feeding } & \multicolumn{1}{c|}{ Mixed feeding } \\
\hline I група & $3,45 \%$ & $62,07 \%$ & $34,48 \%$ \\
\hline p I-II & $\mathrm{p}<0,05$ & $\mathrm{p}>0,05$ & $\mathrm{p}<0,05$ \\
\hline II група & $40,00 \%$ & $44,00 \%$ & $16,00 \%$ \\
\hline III група & $50,00 \%$ & $35,00 \%$ & $15,00 \%$ \\
\hline p I-III & $\mathrm{p}<0,05$ & $\mathrm{p}<0,05$ & $\mathrm{p}<0,05$ \\
\hline p II-III & $\mathrm{p}>0,05$ & $\mathrm{p}>0,05$ & $\mathrm{p}>0,05$ \\
\hline
\end{tabular}

Then we decided to evaluate the $\mathrm{Z}$-score indicator depending on the $\mathrm{C} / \mathrm{A}$ gene polymorphism of COL1A1_1 collagen gene (rs1107946), which had been studied earlier [10]. From the data of the Table 3 and the Figure 1 it can be concluded that children with the CC genotype had normal densitometry indicators, regardless of the type of feeding.

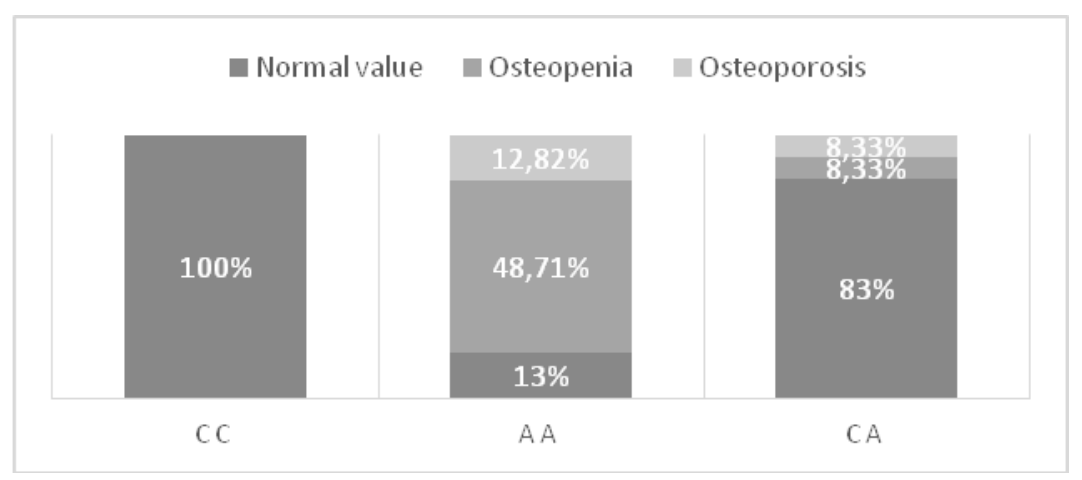

Fig. 1 Densitometry indicators depending on the genotype of the C/A gene polymorphism of COL1A1_1 collagen gene (rs1107946).

The Z-score indicators less than -1SD were found in children with AA and CA genotypes. Osteopenia was significantly less common in children with the AA genotype of the C/A gene polymorphism of COL1A1_1 collagen gene (rs1107946), who received natural or mixed feeding than in children who were exclusively on artificial feeding $(\mathrm{p}<0.05)$. We would like to note that children with the same genotype, but on natural or mixed feeding, had only osteopenia. Among children with the AA genotype who were breastfed, there were changes in bone tissue (63.64\% of children had osteopenia and $22.73 \%$ had osteoporosis). Among heterozygotes who were on artificial feeding, osteoporosis was found in $12.5 \%$. 
Children with the CA genotype on mixed feeding had a decrease in bone tissue density (osteopenia) in $33.33 \%$ of cases.

Table 4. Densitometry (Z-score) indicators depending on the type of feeding and genotype of the C/A gene polymorphism of COL1A1_1 collagen gene (rs1107946)

\begin{tabular}{|c|c|c|c|c|c|c|c|}
\hline $\begin{array}{l}\text { Geno- } \\
\text { type }\end{array}$ & Densitometry & $\begin{array}{l}\text { Natural } \\
\text { feeding }\end{array}$ & Z-score & $\begin{array}{l}\text { Artificial } \\
\text { feeding }\end{array}$ & Z-score & $\begin{array}{l}\text { Mixed } \\
\text { feeding }\end{array}$ & Z-score \\
\hline \multirow[t]{3}{*}{$\mathrm{CC}$} & $\begin{array}{l}\text { Normal value } \\
\%,(\mathrm{n})\end{array}$ & $100 \%(8)$ & $0,98 \pm 1,61$ & $100 \%(8)$ & $0,74 \pm 1,38$ & $100 \%(7)$ & $1,14 \pm 1,2$ \\
\hline & $\begin{array}{l}\text { Osteopenia } \%, \\
\text { (n) }\end{array}$ & - & - & & - & - & - \\
\hline & $\begin{array}{l}\text { Osteoporosis } \\
\%, \text { (n) }\end{array}$ & - & - & & - & - & - \\
\hline \multirow[t]{3}{*}{ AA } & $\begin{array}{l}\text { Normal value } \\
\%,(\mathrm{n})\end{array}$ & $70,00 \%(7)$ & $1,2 \pm 1,1$ & $13,64 \%(3)$ & $1,17 \pm 0,83$ & $71,43 \%(5)$ & $0,68 \pm 0,8$ \\
\hline & \begin{tabular}{|l} 
Osteopenia \\
$(\mathrm{n})$
\end{tabular} & $30,00 \%$ (3) & $\begin{array}{c}- \\
1,47 \pm 0,46^{*}\end{array}$ & $\begin{array}{c}63,64 \% \\
(14)\end{array}$ & $\begin{array}{c}- \\
1,84 \pm 0,57 *\end{array}$ & $28,57 \%(2)$ & $-2,05 \pm 0,21^{*}$ \\
\hline & $\begin{array}{l}\text { Osteoporosis } \\
\%, \text { (n) }\end{array}$ & - & - & $22,73 \%(5)$ & $-3,7 \pm 0,95$ & - & - \\
\hline \multirow[t]{3}{*}{$\overline{A C}$} & $\begin{array}{l}\text { Normal value } \\
\%,(\mathrm{n})\end{array}$ & $100 \%(3)$ & $-0,5 \pm 0,2$ & $87,5 \%(7)$ & $0,3 \pm 0,45$ & $66,67 \%(2)$ & $0,77 \pm 2,16$ \\
\hline & $\begin{array}{l}\text { Osteopenia \% } \\
(\mathrm{n})\end{array}$ & - & - & - & - & $33,33 \%(1)$ & $-1,5$ \\
\hline & $\begin{array}{l}\text { Osteoporosis } \\
\%,(\mathrm{n})\end{array}$ & - & - & $12,5 \%(1)$ & $-2,6$ & - & - \\
\hline
\end{tabular}

It is important to note that among children with AA genotype who were breastfed and had osteopenia, these were children weighing up to $2500 \mathrm{~g}$ (groups I and II). Children with osteopenia on mixed breastfeeding weighed at birth up to $2000 \mathrm{~g}$. Osteopenia in children receiving artificial feeding was found in children of all 3 groups: 50.00\% - group I, $28.57 \%$ group II and 21, 43\% - group III. Osteoporosis in breastfed children was found only among children of the groups I and II.

\section{Discussion}

In an analysis of the current literature, it is known that the relationship between the C/A gene polymorphism of COL1A1_1 collagen gene (rs1107946) and changes in bone tissue density has been studied more often in adults and less frequently in children.

In his study, Vissarionov S.V. researched the relationship between the C/A gene polymorphism of COL1A1_1 collagen gene and the development of scoliosis. The study revealed that children with the A allele and the AA genotype among patients with congenital scoliosis occurred significantly more frequent than in children without scoliotic deformity of the spine. The AA genotype occurred in the group of children with congenital scoliosis more 
than 2 times more often than in the group of children without scoliotic deformity of the spine [11].

Mailyan E. A. et al. proved the connection between the C/A gene polymorphism of COL1A1_1 collagen gene (rs1107946) and lower indicators of the $\mathrm{Ca}++$ levels $(\mathrm{P}=0.037)$ and higher ones and AP $(\mathrm{P}=0.047)$ in women in postmenopause with the AA and CA genotype, which was evidence of an increased bone tissue resorption [12].

The study of the influence of the C/A gene polymorphism of COL1A1_1 collagen gene (rs1107946) on osteoporotic bone changes in the area of proximal department of the left hip showed an uneven distribution of genotypes in the observation groups. The authors found that osteoporotic changes in the femoral neck were significantly more pronounced in women with A allele ( $\mathrm{OSH}=2.46,95 \% \mathrm{CI}: 1.38-4.39, \mathrm{p}=0.006)$. In addition, in the group of patients with osteoporosis of the left femoral neck in comparison with all other women, a somewhat unreliable tendency $(\mathrm{p}=0.064)$ to an increased accumulation of the AA genotype was established [13].

Edith Falco'n-Ramı'rez et al. examined 300 women: 100 women with osteopenia, 100 women with hip fractures, and 100 without any bone tissue changes. The aim of the study was to research the association of polymorphism and low mineral density, osteoporosis, hip fractures. This research found an association with lower indicators of bone mineral density in women who had the AA genotype of the C/A gene polymorphism of COL1A1_1 collagen gene (rs1107946) compared with those who had the CC and CA genotypes; but no statistically significant difference was found. In our study, we proved that osteopenia occurred among children with AA and CA genotypes, while osteoporosis - only in children with AA genotype [14].

In a systematic review, Liting Tong et al. reported that about $31 \%$ of preterm born children had osteopenic changes, which further affected their physical development throughout life, i.e. they had lower weight and height compared to their peers born with normal body weight. Metabolic bone disease could also lead to more frequent fractures. According to our data, osteopenia and osteoporosis were found in about $35.14 \%$ of the examined children [15].

Bandara S. et al. studied the prevalence of osteopenia in preterm born children who were exclusively fed with breast milk and fortified breast milk. They obtained the following results: $36.8 \%$ of children receiving fortified milk had osteopenia, while osteopenia was observed in $48.6 \%$ of cases in breastfed children. But no statistically significant difference was found [16]. Asghar Lotf et al. in their study, no difference between the two feeding 
groups (artificial feeding and mixed feeding) was observed in terms of the occurrence of bone disorders [17]. Michelle N. Körnmann et al. investigated the effect of breastfeeding on bone mineral density, and the increase in breastfeeding volume promoted the increase of the bone tissue density [18]. We also observed such tendency in our study.

\section{Conclusions}

1. According to densitometry data, among all examined children, there were no changes in the skeletal system (Z-score $0.48 \pm 1.20$ ) in $64.86 \%$, osteopenia was registered (Zscore $-1.8 \pm 0.53$ ) in $27.03 \%$ and osteoporosis (Z-score $-3.5 \pm 0.96$ ) was registered in $8.11 \%$. But in children of the group I with body weight at birth of 1500-1999g, osteopenia was registered in $34.48 \%$ of cases; in the group II (2000-24999) in $28.00 \%$ of cases; in the group III ( $2500 \mathrm{~g}$ and more) in $15.00 \%$ of cases. Osteoporosis was found only among children born weighing up to $2500 \mathrm{~g}$.

2. Children of the group I mainly received artificial (62.07\%) and mixed $(34.48 \%)$ feeding. Children of the group II received approximately the same amount of natural (40.00\%) and artificial (44.00\%) feeding, much less often mixed one. In the control group III, $50 \%$ of children were breastfed.

3. Regardless of the type of feeding, no changes in bone tissue were detected in children with the CC genotype of the C/A gene polymorphism of COL1A1_1 collagen gene (rs1107946). The Z-scores indicators less than -1 SD were found in children with the AA and CA genotypes, and only among children with the AA genotype of polymorphism, who received natural or mixed feeding, osteopenia occurred significantly less frequently $(30.00 \%)$ than among children who had exclusively artificial feeding (63.64\%). Osteoporosis was detected only in children with the AA genotype (12.5\%) who were on artificial feeding.

4. To reduce the risk of osteogenesis disorders in children with the AA genotype of the C/A gene polymorphism of COL1A1_1 collagen gene (rs1107946), born with low weight, the breastfeeding should be preferred, for which maximum effort should be made to preserve or restore lactation in mother.

Prospects for further study. In the future, we are planning to assess densitometry indicators depending on the clinical manifestations of rickets.

Financing. The study has been performed in the framework of the planned research scientific work of the Children's Diseases Department of ZSMU entitled "The peculiarities of the development of diseases and the elaboration of the programs of rational nutrition, of therapeutic and rehabilitation measures improvement, and of prevention of distresses in children of different age, who reside in an industrial city" state registration No 114U001397. 


\section{Conflict of interests: none.}

\section{References}

1. Ukarapong, S., Venkatarayappa, S. K. B., Navarrete, C., \& Berkovitz, G. (2017b). Risk factors of metabolic bone disease of prematurity. Early Human Development, 112(0378-3782), 29-34. https://doi.org/10.1016/j.earlhumdev.2017.06.010

2. Faienza, M. F., D’Amato, E., Natale, M. P., Grano, M., Chiarito, M., Brunetti, G., \& D'Amato, G. (2019). Metabolic Bone Disease of Prematurity: Diagnosis and Management. Frontiers in Pediatrics, 7(143). https://doi.org/10.3389/fped.2019.00143

3. Mannan, M. A., Jahan, I., Rahman, M. Z., Hasan, Z., Dey, A. C., \& Shahidullah, M. (2015). Osteopenia of Prematurity: Are We at Risk? Mymensingh Medical Journal: MMJ, 24(3), 631-637. https://www.ncbi.nlm.nih.gov/pubmed/26329969

4. von Websky, K., Hasan, A. A., Reichetzeder, C., Tsuprykov, O., \& Hocher, B. (2018). Impact of vitamin D on pregnancy-related disorders and on offspring outcome. The Journal of Steroid Biochemistry and Molecular Biology, 180(0960-0760), 51-64. https://doi.org/10.1016/j.jsbmb.2017.11.008

5. Dokos, C., Tsakalidis, C., Manaridou, K., Karayianni, P., Kyrkos, I., \& Roussos, I. (2017). Clinical-laboratory findings of bone metabolism in healthy premature and full-term neonates: preliminary results. Clinical Cases in Mineral and Bone Metabolism, 14(2), 167-172. https://doi.org/10.11138/ccmbm/2017.14.1.167

6. Shcherbak V. A., \& Popova N. G. (2015). Osteopenia of prematurity. Zabajkal'skij Medicinskij Vestnik, 1(1998-6173), 143-151. Russian.

7. Al-lawama, M., Abu Alrous, H., Alkhatib, H., Alrafaeh, A., Wakileh, Z., Alawaisheh, B., Saadeh, A., Sharab, J., Badran, E., \& Albsoul-Younes, A. (2019). Nutritional Support of Very Low Birth Weight Infants in a Tertiary Center in a Developing Country. Journal of Clinical Medicine Research, 11(4), 283-288. https://doi.org/10.14740/jocmr3797

8. Faerk J, Peitersen B, Petersen S, Michaelsen KF. Bone mineralisation in premature infants cannot e predicted from serum alkaline phosphatase or serum phosphate. Arch Dis Child Fetal Neonatal. (2002) 87:F133-6. 10.1136/fn.87.2.F133

9. Kulyayev Ye. A., Grafov A.V, Falameyeva O.V, Khrapova Yu.V., Sadovoy M.A. (2013). Study of zoledronic acid preparation rezoklastin fs $5 \mathrm{mg} / 6.25 \mathrm{ml}$ (f-sintez cjsc) in patients with low bone mineral density. «Medicine and Education in Siberia», 2(19950020).

10. Shumna, T. Y., Levchuk, T. O., \& Kamyshnyi, O. M. (2019). Analysis of COL1A1_1 gene (rs1107946) polymorphism as a risk for low birth weightfactor. 
Zaporozhskij Medicinskij ZHurnal, O(4). https://doi.org/10.14739/2310-1210.2019.4.173342

11. Vissarionov S.V., Larionova V.I., Kazarian1 I.V., Filippova A.N., Kostik M.M., Voitovich A.N.,. Rotchev E.V. The gene polymorphisms of COL1A1 and VDR in children with scoliosis // Pediatric Traumatology, Orthopaedics and Reconstructive Surgery. 2017. - T. 5. - №1. - C. 5-12. doi: 10.17816/PTORS515-12 Russian.

12. Maylyan E. A., Reznichenko N. A., Ignatenko G. A. (2018). Blood serum biochemical indicators in postmenopausal women as function of osteoporotic changes and genetic polymorphisms. Krymskij zhurnal eksperimental'noj i klinicheskoj mediciny, 8(2). https://www.elibrary.ru/item.asp?id=36334908 Russian.

13. _Maylyan E. A (2017). Association of collal gene spl polymorphism with bone mineral density in postmenopausal women. Ul'yanovskij mediko-biologicheskij zhurnal, 2. https://www.elibrary.ru/item.asp?id=29392954 Russian.

14. Falcón-Ramírez, E., Hidalgo-Bravo, A., Barredo-Prieto, B. A., Pineda-Gómez, E., \& Valdés-Flores, M. (2015). Association of the COL1A1 gene polymorphisms in Mexican postmenopausal women with fracture or with low bone mineral density at the hip. Aging Clinical and Experimental Research, 28(3), 567-571. https://doi.org/10.1007/s40520-0150449-6

15. Tong, L., Gopal-Kothandapani, J. S., \& Offiah, A. C. (2018). Feasibility of quantitative ultrasonography for the detection of metabolic bone disease in preterm infants systematic review. Pediatric Radiology, 48(11), 1537-1549. https://doi.org/10.1007/s00247018-4161-5

16. Bandara, S., \&amp; Kariyawasam, A. (2010). AO-45. Incidence of osteopenia of prematurity in preterm infants who were exclusively fed breast milk. Early Human Development, 86, S18. doi:10.1016/j.earlhumdev.2010.09.053

17. Lotfi, A., Shiasi, K., Amini, R., Jahangiri, M., Sharif, M. R., Akbari, H., Talari, H., Hajmobini, Z., Hami, K., \& Kashani, H. H. (2016). Comparing the Effects of Two Feeding Methods on Metabolic Bone Disease in Newborns With Very Low Birth Weights. Global Journal of Health Science, 8(1), 249-254. https://doi.org/10.5539/gjhs.v8n1p249

18. Körnmann, M. N., Christmann, V., Gradussen, C. J. W., Rodwell, L., Gotthardt, M., Van Goudoever, J. B., \& Van Heijst, A. F. J. (2017). Growth and Bone Mineralization of Very Preterm Infants at Term Corrected Age in Relation to Different Nutritional Intakes in the Early Postnatal Period. Nutrients, 9(12), 1318. https://doi.org/10.3390/nu9121318 